\title{
PRODUKSI DAN PEMASARAN PRODUK MANISAN PALA "ILOMATA" DI KELURAHAN GIRIAN WERU, KOTA BITUNG
}

\author{
Irene Pricilia Pangumpia \\ Lyndon R.J. Pangemanan \\ Nordy F.L. Waney
}

\begin{abstract}
ABSRACT
The purpose of this research is to describe the process of making candied nutmeg by UD Ilomata and describing Ilomata's candied nutmeg marketing. The research carried out start from preparation in the April until preparation of reports in the June 2016. Data used is primary data obtained through interviews by giving questioners to the owner of UD Ilomata, and from direct observation to the production activity and marketing of Ilomata's candied nutmeg. Data analysis used is descriptive analysis. Data analysis in this research is analysing market margin by calculating cost and the price margins on every channel marketing that involved in the marketing of Ilomata's candied nutmeg and also calculate the Break Even Point. The result of this research shows that Ilomata's candied nutmeg packed in three different packages, 3 ounce package, 2.5 ounce package, and 3 ounce package. Ilomata's candied nutmeg marketed on four stores in Bitung City, two stores in Manado City, a store in Gorontalo province and the marketing directly from producer to the consumer in UD Ilomata. Biggest marketing margin is Rp 5.000 with 16\% share found in the Gorontalo province's channel marketing from the 2.5 ounce package and with the biggest profit margin is $\mathrm{Rp} 3.764$ found in the Bitung CityMart's channel marketing from the 2 ounce package. All of Ilotama's channel marketing can be said efficient because total cost is small seen from the rotation of sold time product. UD Ilotmata's Candied nutmeg business can hold on and exist till today because theres diligence, curiosity and entrepreneurship from the owner namely Mrs. Renny Umar. *lwths*
\end{abstract}

Key words: production, marketing, nutmeg candied, Girian Weru, Bitung

\begin{abstract}
ABSTRAK
Penelitian ini bertujuan untuk mendeskripsikan proses pembuatan manisan pala UD Ilomata dan mendeskripsikan pemasaran manisan pala Ilomata. Penelitian dilaksanakan mulai dari persiapan pada bulan April sampai penyusunan laporan pada bulan Juni 2016. Data yang digunakan adalah data primer yang diperoleh melalui wawancara langsung dengan memberikan kuisioner kepada pemilik usaha UD Ilomata, dan observasi atau pengamatan langsung terhadap kegiatan produksi dan pemasaran manisan pala Ilomata. Analisis data yang digunakan adalah secara deskriptif. Analisis data dalam penelitian ini yaitu menganalisis margin pemasaran dengan cara menghitung besarnya biaya dan menghitung selisih harga pada masing-masing saluran pemasaran yang terlibat dalam kegiatan pemasaran manisan pala Ilomata serta menghitung Break Even Point (BEP). Hasil penelitian menunjukan bahwa manisan pala Ilomata dikemas dalam tiga jenis kemasan yaitu kemasan 2 ons, kemasan 2,5 ons dan kemasan 3 ons. Manisan pala Ilomata dipasarkan ke 4 toko di Kota Bitung, 2 toko di Kota Manado, satu toko di Gorontalo dan pemasaran langsung dari produsen ke konsumen akhir di UD Ilomata. Margin pemasaran paling besar adalah Rp 5.000 dengan share sebesar 16 persen terdapat di saluran pemasaran di Provinsi Gorontalo atas penjualan manisan pala kemasan 2,5 ons dan profit margin paling besar adalah Rp 3.764 terdapat di saluran pemasaran di CityMart Bitung atas penjualan maniasn pala kemasan 2 ons. Semua saluran pemasaran manisan pala Ilomata dapat dikatakan efisien karena total biaya yang dikeluarkan kecil dilihat dari perputaran waktu lama laku produk. Usaha manisan pala dari UD Ilomata bisa bertahan dan eksis sampai sekarang berkat adanya ketekunan, rasa ingin tahu serta jiwa wirausaha dari pemilik yaitu Ibu Renny Umar.
\end{abstract}

Kata kunci: produksi, pemasaran, manisan pala, Kelurahan Girian Weru, Kota Bitung 


\section{PENDAHULUAN}

\section{Latar Belakang}

Indonesia merupakan negara agraris dimana sebagian besar penduduk bermata pencaharian dalam bidang pertanian. Pertanian dalam arti luas meliputi perikanan, peternakan, kehutanan, perkebunan, hortikultura, dan tanaman pangan. Perkebunan adalah usaha pemanfaatan lahan yang luas untuk menghasilkan suatu komoditi yang perdagangannya dalam skala besar. Tanaman perkebunan mencakup komoditas tanaman semusim dan tanaman tahunan. Tanaman semusim berumur kurang dari satu tahun dan hanya satu kali produksi. Tanaman tahunan adalah tanaman berkayu keras yang umurnya lebih dari satu tahun dan berproduksi lebih dari satu kali seperti cokelat, cengkeh, pala, dan kelapa.

Pala sudah dikenal sebagai tanaman rempah sejak abad ke 16. Tanaman pala tersebar di kepulauan Bangka dan Riau. Tanaman pala dapat tumbuh sampai mencapai 18 meter. Tanaman pala dapat dipetik 3-4 kali dalam satu tahun dengan interval waku 3-4 bulan. Buah pala dipetik dengan cara dipanjat atau menunggu buah jatuh ketika sudah matang. Buah pala terdiri dari daging buah, fulli, dan biji (Suluh, 2015). Pala merupakan komoditi penting karena menjadi penyumbang pendapatan petani (Supit, 2015). Pala dikenal sebagai tanaman yang mempunyai nilai ekonomis yang tinggi karena cakupan pasarnya yang luas dengan permintaan pasar yang besar. Pala Indonesia yang diperdagangkan dalam perdagangan Internasional dikenal dengan sebutan "Banda Nutmeg".

Tanaman pala mulai dikembangkan di Sulawesi Utara sekitar tahun 1748. Komoditas terbesar yang dihasilkan di Sulawesi Utara adalah pala. Buah pala dapat diolah menjadi berbagai macam produk. Fuli dan biji pala dapat diolah untuk menghasilkan obat-obatan dan bumbu masakan. Daging buah pala dapat diolah untuk menghasilkan selai pala, sirup pala, manisan pala, dan permen pala. Pengolahan daging buah pala menjadi manisan pala biasanya dilakukan oleh usaha rumah tangga. Manisan pala termasuk makanan ringan dari pengolahan daging buah pala dan merupakan produk khas Provinsi Sulawesi Utara sebagai produk souvenir atau ole-ole. Kegiatan pengolahan produk dengan menggunakan bahan baku pertanian dikenal dengan sebutan agroindustri.

Produksi adalah kegiatan untuk menciptakan atau menghasilkan suatu barang dan jasa untuk memenuhi kebutuhan konsumen. Produksi merupakan kegiatan untuk meningkatkan manfaat suatu barang dengan cara mengubah bentuk (form utility), memindahkan tempat (place utility), dan menyimpan (store utility). Kegiatan menciptakan barang dan jasa memerlukan biaya yang disebut dengan biaya produksi. Biaya produksi terdiri atas biaya tetap dan biaya variabel. Biaya tepat adalah jenis biaya yang besar kecilnya tidak tergantung pada besar kecilnya produksi. Biaya variabel adalah biaya yang besar kecilnya berhubungan langsung dengan besarnya produksi (Moehar, 2002).

Usaha pengolahan manisan pala sudah sejak lama dilakukan oleh masyarakat dalam skala industri rumah tangga (home industry), dan pada tahun terakhir ini telah dikembangkan menjadi industri kecil dan menegah. Berbagai proses kegiatan untuk menghasilkan produk manisan pala, unsur kegiatan pemasaran merupakan mata rantai yang perlu diperhatikan demi kelangsungan usaha. Pemasaran merupakan kegiatan manusia yang didasarkan untuk memenuhi dan memuaskan kebutuhan dan keinginan melalui proses pertukaran (Assauri, 2014). Pemasaran merupakan satu diantara komponen pasca produksi yag merupakan kunci dalam mengembangkan suatu usahan (Handayani dan Nurlaila, 2011). Pemasaran adalah suatu sistem dari kegiatan usaha yang ditujukan untuk merencanakan, menentukan harga, mempromosikan, dan mendistribusikan barang/jasa yang memuaskan kebutuhan pembeli yang potensial,juga tidak berakhir pada waktu penjualan atau transaksi. Keputusan-keputusan yang diambil dalam bidang pemasaran harus ditunjukan untuk 
menentukan produk, pasar, harga, promosi, dan sistem distribusinya (Pasaribu, 2012).

Proses penyaluran hasil produksi dilakukan dengan bantuan lembaga pemasaran, perantara yang disebut dengan saluran pemasaran. Saluran pemasaran adalah sekelompok lembaga yang mengadakan kerjasama untuk mencapai pasar-pasar tertentu. Lembaga pemasaran adalah orang atau badan usaha yang secara langsung terlibat dalam proses penyaluran barang dari produsen ke konsumen (Sudiyono, 2002). Biaya yang dikeluarkan kecil jika jarak antara produsen dengan konsumen dekat. Biaya yang dikeluarkan akan semakin mahal jika jarak antara produsen dengan konsumen jauh. Komoditas pertanian yang dipasarkan berbeda harganya di tingkat pengecer (konsumen akhir) dan harga di tingkat petani. Perbedaan harga itu disebut margin pemasaran (Soekartawi, 2002).

Suatu sistem dapat dikatakan efisien apabila dapat memberikan kepuasan kepada seluruh pihak yang terlibat dalam proses pemasaran. Sistem pemasaran yang tidak efisien akan mengakibatkan kecilnya bagian yang diterima oleh produsen. Efisiensi adalah penggunan input yang sekecil-kecilnya untuk mendapatkan produksi yang sebesar-besarnya (Soekartawi, 2002). Dikatakan efisiensi apabila sumberdaya tersebut menghasilkan keluaran atau output yang melebihi masukan atau input. Suatu komoditas akan mempunyai efisiensi pemasaran yang tinggi jika harga yang diterima produsen dengan harga yang harus dibayar konsumen relatif kecil yang dapat dilihat dari margin pemasarannya (Tampi, 2002).

Manisan pala Ilomata merupakan suatu usaha rumah tangga (home industry) yang bertempat di Sagerat Bitung dan berdiri pada tahun 1980. Kemudian pada tahun 1991 usaha ini menjadi UD Ilomata dan berpindah lokasi ke Girian Weru II Kecamatan Girian Weru Kota Bitung. Modal yang digunakan berasal dari milik keluarga. Bahan baku manisan pala dibeli dari petani pala. Tenaga kerja yang terlibat berasal dari anggota keluarga. Kegiatan pemasaran manisan pala Ilomata pada awalnya dilakukan dengan menjual secara langsung (berjualan keliling) dan disalurkan ke toko-toko di kota Bitung. Kegiatan promosi telah dilakukan dengan mengikuti pameran diberbagai tempat di Provinsi Sulawesi Utara. Selain disalurkan ke toko-toko di Kota Bitung, manisan pala ilomata juga disalurkan dibeberapa toko di Kota Manado. Pemasaran manisan pala Ilomata juga sudah sampai ke luar daerah seperti Provinsi Papua Barat Kota Sorong. Kegiatan pemasaran membutuhkan jasa lembaga pemasaran dan pengeluaran biaya yang cukup besar. Suatu usaha bisa bertahan lama karena bantuan jasa dari lembaga pemasaran dan adanya manajemen yang baik dari perusahaan. Sejak didirikan tahun 1980 dalam skala industri rumah tangga, Manisan Pala Ilomata mampu bertahan dan bersaing dalam usaha manisan pala sehingga menarik untuk diteliti bagaimana proses pembuatan Manisan Pala Ilomata di Kelurahan Girian Weru Kota Bitung dan pemasaran manisan pala Ilomata serta berapa keuntungan yang diperoleh.

\section{Perumusan Masalah}

Berdasarkan latar belakang, masalah yang ingin diteliti adalah:

1. Bagaimana proses pembuatan Manisan Pala di UD Ilomata?

2. Bagaimana proses pemasaran Manisan Pala Ilomata?

3. Berapa besar keuntungan yang diperoleh UD Ilomata?

\section{Tujuan Penelitian}

Penelitian ini dilakukan dengan tujuan untuk:

1. Mendeskripsikan proses pembuatan manisan pala di UD Ilomata.

2. Menganalisis proses pemasaran manisan pala Ilomata.

3. Menganalisis keuntungan yang diperoleh UD Ilomata.

\section{Manfaat Penelitian}

1. Bahan referensi untuk penelitian

2. Memberi masukan kepada pemilik usaha manisan pala Ilomata untuk menilai sejauh mana efisiensi saluran pemasaran yang ada selama ini.

3. Menambah pengetahuan dalam bidang tataniaga pala. 


\section{METODELOGI PENELITIAN}

\section{Waktu dan Tempat Penelitian}

Penelitian ini akan dilaksanakan mulai dari persiapan bulan April sampai penyusunan laporan pada bulan Juni 2016. Tempat penelitian berlokasi di UD Ilomata Kelurahan Girian Weru II Kecamatan Girian Weru Kota Bitung dan tokotoko yang menjual manisan Pala Ilomata di kota Manado

\section{Metode Pengumpulan Data}

Data yang dikumpulkan dalam penelitian ini adalah data primer yang diperoleh melalui wawancara langsung dan memberikan kuisioner kepada pemilik usaha UD Ilomata, dan observasi atau pengamatan langsung terhadap kegiatan produksi dan pemasaran manisan pala Ilomata.

\section{Konsep Pengukuran Variabel}

1. Jumlah Produksi: banyaknya manisan pala yang dihasilkan dalam 1 kali produksi (Kg/bulan).

2. Biaya Produksi: besarnya biaya yang dikeluarkan pada pengolahan manisan pala per bulan.

a. Biaya Tetap (Fixed Cost)

- Biaya Pajak (Rp)

- Biaya Penyusutan Peralatan (Rp)

b. Biaya Variabel (Variabel Cost)

- Biaya Bahan Baku Buah Pala (Rp/Kg)

- Bahan Penolong

- Gula (Rp/Kg)

- Garam (Rp/Bungkus)

- Cabe $(\mathrm{Rp} / \mathrm{Kg})$

- Biaya Perlengkapan

- Kemasan Plastik Ukuran 2 Ons (Rp/Pak)

- Kemasan Plastik Ukuran 2,5 Ons (Rp/Pak)

- Kemasan Toples Mika Ukuran 3 Ons (Rp/Lusin)

- Biaya Tenaga Kerja (Rp/Orang)

- Biaya Listrik (Rp/Bulan)

- Biaya Air (Rp/Bulan)

3. Biaya Pemasaran (Rp)

- Biaya Pengemasan dan Pengepakkan Rp/bks)

- Biaya Pengangkutan (Rp/bks)

- Biaya Transportasi (Rp/hari)

- Biaya Pengiriman (Rp/bks)
4. Harga jual: harga yang ditetapkan oleh pemilik manisan pala Ilomata (Rp/bungkus)

5. Keuntungan: laba yang diterima dari penjualan produk.

\section{Metode Analisis Data}

1. Mendeskripsikan proses produksi manisan pala Ilomata.

2. Menganalisis pemasaran manisan pala Ilomata. Analisis data dalam penelitian ini yaitu menganalisis margin pemasaran dengan cara menghitung besarnya biaya dan menghitung selisih harga pada masing-masing saluran pemasaranyang terlibat dalam kegiatan pemasaran manisan pala Ilomata serta menghitung Share dan Break Event Point (BEP).

a. Sudiyono, (2002) Untuk mengetahui besarnya Margin Pemasaran dihitung menggunakan rumus:

$$
\mathrm{MP}=\mathrm{Pr}-\mathrm{Pf}
$$

Dimana :

$\mathrm{Mr}=$ Margin Pemasaran

$\operatorname{Pr}=$ Harga di tingkat Konsumen $(\mathrm{Rp} / \mathrm{Kg})$

$\mathrm{Pf}=$ Harga di tingkat Produsen $(\mathrm{Rp} / \mathrm{Kg})$

b. Adiwilaga, (1996) Keuntungan yang diperoleh setiap lembaga pemasaran dihitung menggunakan rumus:

$\Pi=\mathrm{M}-\mathrm{Bp}$

Dimana:

$\Pi=$ Keuntungan Pemasaran

$\mathbf{M}=$ Margin Pemasaran

Bp $=$ Biaya Pemasaran

c. Sudiyono, (2002) mengatakan bahwa Share dapat dihitung menggunakan rumus:

Dimana:

$$
\mathrm{S}=\frac{\mathrm{Pf}}{\mathrm{Pr}} \times 100 \%
$$

$\mathrm{S} \quad=$ Share

Pf = Harga ditingkat Produsen $(\mathrm{Rp} / \mathrm{Kg})$

$\operatorname{Pr} \quad=$ Harga ditingkat Konsumen $(\mathrm{Rp} / \mathrm{Kg})$

Jika nilai persentase Margin Pemasaran rendah dan nilai persentase Share lebih besar dari 50\% maka saluran pemasaran tersebut dianggap efisien.

d. Halim dan Bambang, (2005) Break Event Point (BEP) dapat dihitung mengunakan rumus:

$$
\mathrm{BEP}_{\text {Unit }}=\frac{\text { Total Biaya }}{\text { Harga Jual per Unit }- \text { Biaya Variabel per Unit }}
$$


HASIL DAN PEMBAHASAN

\section{Deskripsi Umum Industri Manisan Pala Ilomata}

UD Ilomata adalah satu diantara usaha kecil menengah (UKM) yang mengolah daging buah pala menjadi manisan pala di Kota Bitung. Pemilik UD Ilomata adalah Ibu Renny Umar, berumur 67 tahun. UD Ilomata berawal dari niat baik untuk memanfaatkan daging buah pala yang tidak dimanfaatkan di kebun pala yang ada di sekitar pekarangan rumah. Niat baik tersebut diawali dengan mengolah daging buah pala menjadi manisan pala dengan cara mencoba-coba. Usaha mengolah daging buah pala menjadi manisan pala dimulai pada tahun 1980 yang berlokasi di Sagerat Bitung. Ketekunan, rasa ingin tahu serta jiwa wirausaha akhirnya membawa usaha ini menjadi Usaha Dagang (UD) Ilomata pada tahun 1991. Pemilik usaha ini berpindah dari kelurahan Sagerat ke lokasi barudi Kelurahan Girian Weru II Kecamatan Girian Weru Kota Bitung, ketika menjadi usaha dagang. Tenaga kerja dalam usaha ini berjumlah 4 orang terdiri dari 1 orang tenaga administrasi dan 3 orang tenaga teknis yang membantu mengerjakan pengolahan buah pala menjadi manisan daging buah pala. Tenaga administrasi berasal dari luar keluarga, sedangkan tenaga pembantu masih merupakan anggota keluarga dari pemilik usaha.

Struktur organisasi UD Ilomata sangat sederhana. Struktur organisasi UD Ilomata dapat dilihat pada Gambar 1.

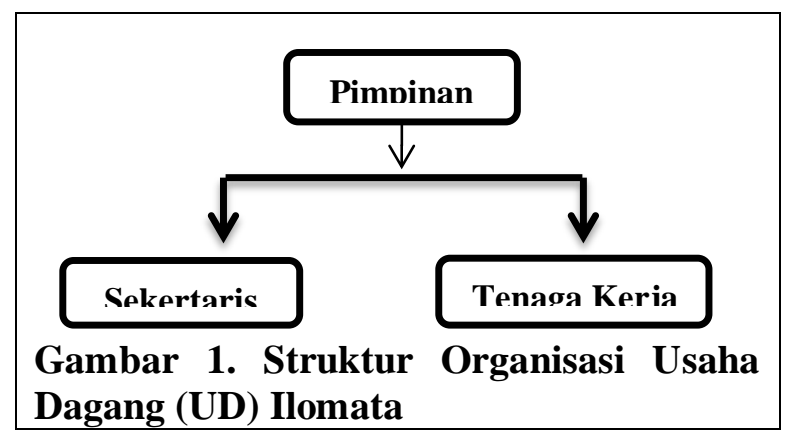

Struktur organisasi usaha dagang Ilomata sebagaimana yang diperlihatkan pada Gambar 1, semua kegiatan mulai dari proses produksi sampai kegiatan pemasaran dikendalikan langsung oleh pimpinan yang merupakan pemilik UD Ilomata.

\section{Produksi Manisan Pala Ilomata}

Kegiatan produksi manisan pala Ilomata dilakukan di UD Ilomata yang merupakan rumah tinggal dari pemilik usaha yang berlokasi di Jalan Hosana Kelurahan Girian Weru Kota Bitung.

\section{Kegiatan Produksi}

Bahan baku buah pala diperoleh dengan memesan dari petani pala yang sudah menjadi langganan. Bahan baku yang dipesan sudah dalam bentuk daging buah pala bersih. Bahan baku yang dipesan, diantar oleh petani ke tempat produksi (UD Ilomata) dengan tidak ada biaya tambahan. Bahan baku daging buah pala yang digunakan dalam satu kali kegiatan produksi sebanyak 300 $\mathrm{kg}$. Peralatan yang digunakan adalah pisau kupas, pisau iris dan mesin pres. Tenaga kerja pada industri ini berjumlah 4 orang. Satu orang tenaga tetap (sekertaris) dan 3 orang bekerja sebagai tenaga kerja borongan. Pembentukan (pengirisan) daging buah pala dilakukan oleh 3 orang tenaga kerja borangan. Daging buah pala sebanyak 300 $\mathrm{kg}$ dibentuk (diiris) menjadi 4 macam yaitu diiris tipis-tipis, bentuk jari, belah dua, dan kembang. Setelah daging buah pala dipres (dikeluarkan airnya), beratnyamenjadi $270 \mathrm{~kg}$. Daging buah pala yang telah dipress diletakkan dalam wadah sebanyak 15 loyang masing-masing berisi $18 \mathrm{~kg}$ daging buah pala. Daging buah pala yang diiris tipis sebanyak 7 loyang atau setara dengan 126 $\mathrm{kg}$, bentuk jari sebanyak 5 loyang atau setara dengan90 $\mathrm{kg}$, belah dua sebanyak 2 loyang atau setara dengan $36 \mathrm{~kg}$, dan 1 loyangdaging buah pala berbentuk kembang atau setara dengan $18 \mathrm{~kg}$. Bahan penolong yang digunakan adalah $270 \mathrm{~kg}$ gula pasir, 20 bungkus garam, dan $1,5 \mathrm{~kg}$ cabe. Pengupasan buah pala dilakukan oleh petani. Peredaman daging buah pala dengan gula dan garam dilakukan oleh pemilik usaha. Pengemasan manisan pala Ilomata untuk disalurkan ke tokotoko di Kota Bitung dan Manado dilakukan oleh 2 orang tenaga kerja borongan. Pengemasan 
manisan pala Ilomata untuk disalurkan ke Gorontalo dilakukan oleh pemilik UD Ilomata. Kemasan yang digunakan untuk mengemas manisan pala Ilomata ada 3 jenis yaitu kemasan plastik ukuran 2 ons sebanyak 500 bungkus, kemasan plastik 2,5 ons sebanyak 500 bungkus, dan toples mika 3 ons sebanyak 4 lusin (48 buah). Kemasan plastik ukuran 2 ons, 2,5 ons dan toples mika 3 ons disablon dengan logo UD Ilomata. Sebelum dikemas, untuk manisan pala pedas dicampur dengan cabe. Tinta yang digunakan untuk sablon kemasan adalah 1 kaleng tinta hitam.

\section{Pengolahan Manisan Pala Ilomata}

Pengolahan manisan pala Ilomata dilakukan oleh tenaga kerja borongan. Proses pengolahan manisan pala Ilomata adalah sebagai berikut:

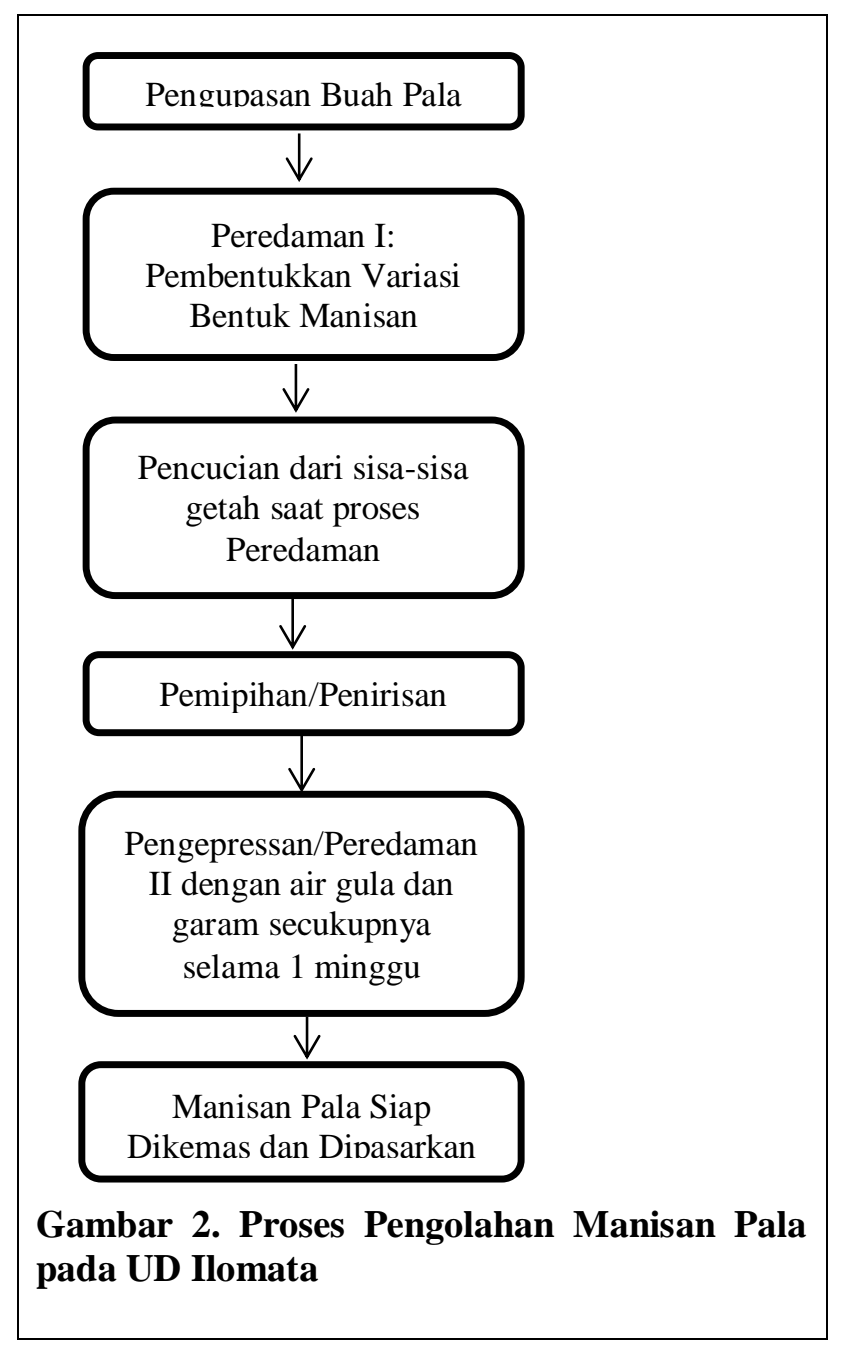

1. Pengupasan Buah Pala
Buah pala dikupas dari kulitnya dengan menggunakan pisau khusus kemudian dimasukkan ke dalam ember/loyang berisi air.

2. Peredaman I (Pembentukkan variasi bentuk manisan)

Daging buah pala yang sudah dikupas kemudian diredam selama satu malam. Daging buah pala yang telah direndam kemudian dibentuk sesuai selera (diiris tipis, diiris bentuk jari, dibelah dua dan bentuk kembang).

3. Pencucian Daging Buah Pala

Daging buah pala yang sudah dibentuk (diiris) kemudian dicuci untuk membersihkan getah lalu ditiriskan.

4. Pemipihan/Penirisan Daging Buah Pala Daging buah pala yang sudah dibentuk kemudian dicuci lalu ditiriskan.

5. Pengepresan/Peredaman II

Daging buah pala yang sudah ditiriskan kemudian diredam dalam wadah berisi gula, garam selama \pm 1 minggu. Manisan pala dihasilkan setelah 1 minggu diredam. Manisan pala tersebut siap dikemas dan dipasarkan dengan merk Manisan pala Ilomata. Manisan pala dengan rasa pedas, dibuat dari manisan pala yang diberi campuran cabe yang telah dihaluskan.

Daging buah pala seberat $270 \mathrm{~kg}$ yang telah dibentuk atau diiris, dimasukkan kedalam wadah dan dicampur dengan $270 \mathrm{~kg}$ gula pasir dan 20 bungkus garam. Daging buah pala, gula pasir dan garam diredam selama 1 minggu. Daging buah pala yang telah direndam selama 1 minggu, kemudian dikemas menjadi manisan buah pala yang siap dipasarkan. Manisan pala Ilomata dikemas dalam 3 jenis kemasan yaitu kemasan plastik 2 ons, kemasan plastik 2,5 ons, dan kemasan toples mika 3 ons. Manisan pala rasa pedas biasanya dicampur dengan cabe yang telah dihaluskan sebelum dikemas.

\section{Biaya Produksi Manisan Pala Ilomata}

Biaya produksi manisan pala merupakan keseluruhan biaya yang dikeluarkan untuk menghasilkan manisan. Biaya-biaya yang 
Tabel 1. Penyusutan Peralatan Yang Digunakan Dalam Kegiatan Produksi Manisan Pala Ilomata dan Nilai Penyusutan per Tahun

\begin{tabular}{llcccccc}
\hline No & Peralatan & $\begin{array}{c}\text { Jumlah } \\
\text { (unit) }\end{array}$ & $\begin{array}{c}\text { Harga } \\
\text { Satuan } \\
(\mathbf{R p})\end{array}$ & $\begin{array}{c}\text { Nilai Awal } \\
(\mathbf{R p})\end{array}$ & $\begin{array}{c}\text { Nilai } \\
\text { Akhir } \\
(\mathbf{R p})\end{array}$ & $\begin{array}{c}\text { Umur } \\
\text { Ekonomi } \\
(\mathbf{T h n})\end{array}$ & $\begin{array}{c}\text { Biaya } \\
\text { Penyusuta } \\
\mathbf{n}(\mathbf{R p})\end{array}$ \\
1. & Pisau & 6 & 20.000 & 120.000 & 58.800 & 2 & 30.600 \\
2. & Loyang & 10 & 35.000 & 350.000 & 171.500 & 2 & 89.250 \\
3. & Wadah & 10 & 55.000 & 550.000 & 269.500 & 2 & 140.250 \\
4. & Mesin Pres & 2 & 80.000 & 160.000 & 38.400 & 4 & 30.400 \\
5. & Timbangan & 2 & 120.000 & 240.000 & 57.600 & 4 & 45.600 \\
6. & Print & 1 & 450.000 & 450.000 & 108.000 & 4 & 85.500 \\
\hline & & & & & & & $\mathbf{4 2 1 . 6 0 0}$
\end{tabular}

dikeluarkan untuk menghasilkan manisan pala padaUD Ilomata adalah sebagai berikut

\section{Biaya Tetap}

Biaya tetap merupakan suatu biaya yang pengeluarannya tidak tergantung pada banyaknya produksi. Biaya tetap dalam usahan ini berupa biaya pajak dan biaya penyusutan peralatan.

a. Biaya Pajak

Pajak di UD Ilomata adalah pajak pertambahan nilai yaitu sebesar Rp. 7.000 per minggu.

b. Biaya Penyusutan Peralatan

Manisan pala UD Ilomata dibuat dengan menggunakan beberapa peralatan dan mesin sederhana. Peralatan tersebut terdiri atas pisau, loyang, wadah, timbangan dan printer. Mesin sederhana yang digunakan adalah mesin press. Printer digunakan untuk mencetak label, sedangkan mesin press digunakan untuk kemasan manisan pala. Peralatan dan mesin yang digunakan termasuk dalam komponen barang modal. Biaya untuk barang modal tersebut termasuk komponen biaya tetap yang dihitung berdasarkan penyusutannya. Perhitungan biaya penyusutan menggunakan metode garis lurus. Hasil perhitungan penyusutan dan nilai penyusutan barang modal pada UD Ilomata disajikan pada Tabel 1.

Total biaya penyusutan tahunan peralatan dan mesinpada UD Ilomata adalah sebesar Rp. 421.600. Biaya penyusutan per bulan sebesar Rp. 35.133,33 dan biaya penyusutan per minggu adalah $8.783,32$.

\section{Biaya Variabel}

Biaya variabel merupakan biaya yang pengeluarannya tergantung pada banyaknya produksi. Biaya variabel dalam usaha ini berupa biaya bahan baku, biaya bahan penolong, biaya tenaga kerja, biaya kemasan, biaya listrik, biaya air, dan biaya tinta untuk sablon kemasan.

\section{a. Biaya Bahan Baku}

Satu kali produksi UD Ilomata menggunakan $300 \mathrm{~kg}$ daging buah pala bersih yang dibagi dalam 15 karung. Harga $1 \mathrm{~kg}$ daging buah pala bersih adalah Rp. 7.000 per kg. Total biaya yang dikeluarkan untuk pembelian bahan baku adalah sebesar Rp. 2.100.000.

\section{b. Biaya Bahan Penolong}

Bahan penolong yang digunakan dalam pengolahan manisan pala Ilomata adalah gula pasir, garam, dan cabe. Gula pasir yang 
digunakan adalah 6 karung berisi $50 \mathrm{~kg}$ per karung atau $300 \mathrm{~kg}$. Harga satu karung gula pasir Rp. 800.000 atau Rp. 16.000 per $\mathrm{kg}$. Biaya yang dikeluarkan untuk pembelian 6 karung gula pasir adalah sebesar Rp. 4.800.000. Penggunaan garam untuk satu kali produksi adalah 20 bungkus dengan harga Rp. 1000 per bungkus. Biaya yang dikeluarkan untuk pembelian garam adalah sebesar Rp. 20.000. Penggunaan cabe dalam satu kali produksi adalah $1,5 \mathrm{~kg}$ dengan harga Rp. 15.000 per $\mathrm{kg}$ maka total biaya untuk pembelian cabe yaitu Rp. 22.500. Total biaya yang dikeluarkan untuk pembelian $300 \mathrm{~kg}$ gula pasir, 20 bungkus garam dan $1,5 \mathrm{~kg}$ cabe adalah sebesar $\mathrm{Rp}$. 4.842.500.

\section{c. Tenaga Kerja}

Tenaga kerja pada industri ini berjumlah 4 orang terdiri dari 3 orang anggota keluarga dan 1 orang bukan anggota keluarga. Tiga orang bekerja sebagai tenaga kerja borongan harian dan satu orang tenaga kerja tetap (sekertaris). Tenaga kerja tetap diberikan upah Rp.1.500.000 per bulan. Tenaga kerja borongan diberikan upah berbeda. Pengirisan dan pembentukkan daging buah pala diberikan upah Rp. 25.000 per hari. Pengirisan dan pembentukkan daging buah pala dilakukan oleh 3 orang selama 2 hari. Biaya yang dikeluarkan untuk membayar upah 3 orang tenaga kerja dari kegiatan pengirisan dan pembentukkan daging buah pala dalam satu hari Rp.75.000. Total biaya yang dikeluarkan untuk membayar upah 3 orang tenaga kerja dalam 2 hari dari kegiatan pengirisan dan pembentukkan daging buah pala adalah sebesar Rp. 150.000. Pengemasan dan pengepakan manisan pala Ilomata dilakukan oleh 2 orang tenaga kerja borongan dan pemilik usaha. Pengemasan dan pengepakan dilakukan sebanyak 3 kali dalam satu kali produksi. Biaya pengemasan dan pengepakan adalah Rp. 50.000 per hari. Biaya yang dikeluarkan untuk membayar upah 2 orang tenaga kerja dari kegiatan pengemasan dan pengepakan manisan pala Ilomata dalamsatu hari Rp. 100.000. Total biaya yang dikeluarkan untuk membayar upah 2 orang tenaga kerja dalam 3 hari adalah sebesar Rp. 200.000. Total biaya yang dikeluarkan untuk membayar upah 4 orang tenaga kerja dalam kegiatan produksi pada bulan Mei adalah sebesar Rp. 1.850.000.

\section{d. Kemasan}

Manisan Pala Ilomata dikemas dalam tiga jenis kemasan plastik yaitu kemasan 2 ons, kemasan 2.5 ons, dan toples mika 3 ons. Satu pak (500 lembar) kemasan plastik ukuran 2 ons dibeli dengan harga Rp. 35.000, satu pak (500 lembar) kemasan plastik ukuran 2,5 ons dengan harga Rp. 35.000, dan 4 lusin toples mika dengan harga Rp. 15.000 per lusin. Biaya yang dikeluarkan untuk pembelian 4 lusin toples mika adalah sebesar Rp. 60.000. Total biaya yang dikeluarkan untuk pembelian 3 jenis kemasan adalah sebesar Rp. 130.000.

\section{e. Biaya Listrik}

Proses produksi manisan pala Ilomata memakai listrik pulsa. Pembelian pulsa listrik untuk 1 kali produksi dilakukan setiap 2 minggu sekali atau 2 kali dalam 1 bulan. Biaya yang dikeluarkan untuk pembelian pulsa listrik dalam 2 minggu adalah sebesar Rp. 50.000. Total biaya yang dikeluarkan untuk pembelian pulsa listrik dalam satu kali produksi manisan pala adalah sebesar Rp. 100.000. Pengolahan manisan pala menggunakan 2 buah lampu dengan daya sebesar 25 watt per lampu. Pemakaian listrik untuk kegiatan produksi manisan pala dalam satu kali produksi yaitu selama 2 jam. Biaya pemakaian listrik dalam satu kali kegiatan produksi adalah sebesar Rp. 15.000.

\section{f. Biaya Air}

Penggunaan air dalam satu kali kegiatan produksi manisan pala adalah sebanyak 3 kubik. Harga air per kubik adalah Rp. 8.000. Total biaya yang dikeluarkan untuk pembayaran iuran air dalam satu kali kegiatan produksi adalah sebesar Rp. 24.000.

\section{g. Tinta Sablon}

Kemasan plastik disablon dengan logo UD Ilomata. Pemakaian tinta untuk sablon kemasan plastik adalah 1 kaleng dengan harga Rp. 60.000 per kaleng. 
Tabel 2. Biaya Variabel Industri Manisan Pala Ilomata Per Satu Kali Kegiatan Produksi

\begin{tabular}{|c|c|c|c|c|c|}
\hline No & Pengeluaran & Satuan & Jumlah & $\begin{array}{c}\text { Harga } \\
\text { Satuan } \\
(\mathbf{R p})\end{array}$ & Jumlah Biaya (Rp) \\
\hline 1. & Bahan Baku & $\mathrm{Kg}$ & 300 & 7.000 & 2.100 .000 \\
\hline \multirow[t]{4}{*}{2.} & Bahan Penolong & & & & \\
\hline & - Gula Pasir & $\mathrm{Kg}$ & 300 & 16.000 & 4.800 .000 \\
\hline & - Cabe & $\mathrm{Kg}$ & 1,5 & 15.000 & 22.500 \\
\hline & - Garam & Bks & 20 & 1.000 & 20.000 \\
\hline 3. & Listrik & Watt & 50 & & 15.000 \\
\hline 4. & Air & Kubik & 3 & 8.000 & 24.000 \\
\hline \multirow[t]{4}{*}{5.} & Kemasan Plastik & & & & \\
\hline & -2 ons & Pak & $1(500 \mathrm{lmbr})$ & 35.000 & 35.000 \\
\hline & - $\quad 2,5$ ons & Pak & $1(500 \mathrm{lmbr})$ & 35.000 & 35.000 \\
\hline & - $\quad$ Toples mika 3 ons & Lusin & 4 (48 buah) & 15.000 & 60.000 \\
\hline 6. & Tinta Sablon & Kaleng & 1 & 60.000 & 60.000 \\
\hline \multirow[t]{2}{*}{7.} & Tenaga Kerja & Orang & 4 & & 1.850 .000 \\
\hline & Total Biaya & & & & 9.021 .500 \\
\hline
\end{tabular}

Keterangan: Perhitungan Biaya didasarkan atasperhitungan biaya pada bulan Mei tahun 2016.

UD Ilomata menggunakan $300 \mathrm{~kg}$ daging buah pala bersih sebagai bahan baku utama untuk diolah menjadi manisan pala. Harga $1 \mathrm{~kg}$ daging buah pala adalah Rp. 7.000. Total biaya yang dikeluarkan untuk membeli $300 \mathrm{~kg}$ daging buah pala adalah sebesar $\mathrm{Rp}$. 2.100.000. Bahan penolong yang digunakan dalam kegiatan produksi manisan pala adalah gula pasir sebanyak $300 \mathrm{~kg}$ dengan harga $\mathrm{Rp}$. 16.000 per $\mathrm{kg}$. Total biaya yang dikeluarkan untuk pembelian $300 \mathrm{~kg}$ gula pasir adalah sebesar Rp. 4.800.000. Bahan penolong lainnya adalahcabe sebanyak $1,5 \mathrm{~kg}$ dengan harga $\mathrm{Rp}$. 15.000 per $\mathrm{kg}$. Total biaya pembelian cabe sebesar Rp. 22.500. Bahan penolong lainnya adalah garam. Garam yang digunakan sebanyak 20 bungkus. Harga garam adalah Rp. 1.000 per bungkus, sehingga total biaya untuk pembelian 20 bungkus garam adalah sebesar Rp. 20.000.

Biaya-biaya lainnya yang ikut diperhitungkan dalam memproduksi manisan pala di UD Ilomata adalah biaya listrik dan biaya air bersih serta biaya pemberian label. Biaya listrik pada bulan Mei 2016 adalah Rp. 15.000. Biaya air bersih yang digunakan dalam proses produksi manisan pala Ilomata (peredaman dan pencucian) adalah sebesar Rp. 24.000. Kemasan manisan pala diberi label UD 
Ilomata. Pemberian label kemasan dengan logo UD Ilomata menggunakan 1 kaleng tinta dengan harga Rp. 60.000.

UD Ilomata menggunakan 4 orang tenaga kerja, terdiri atas 1 orang tenaga administrasi dan 3 orang tenaga teknisproduksi. Tenaga administrasi diberi upah Rp. 1,5 juta per bulan. Tenaga teknis produksi diberi upah harian sebesar Rp. 25.000 dan Rp. 50.000 per hari. Jumlah hari kerja tenaga kerja harian dalam satu bulan rata-rata adalah 4 hari kerja. Upah tenaga kerja harian dalam sebulan ratarata sebesar Rp. 350.000. Total biaya untuk membayar 4 orang tenaga kerja adalah $\mathrm{Rp}$. 1.850.000.

Manisan pala Ilomata dikemas dalam 3 jenis kemasan yaitu kemasan plastik 2 ons, kemasan plastik 2,5 ons, dan toples mika 3 ons. Biaya yang dikeluarkan untuk pembelian 1 pak (500 lembar) kemasan plastik 2 ons adalah sebesar Rp. 35.000. Biaya yang dikeluarkan untuk pembelian 1 pak (500 lembar) kemasan plastik 2,5 ons adalah sebesar Rp. 35.000. Penggunaan toples mika sebanyak 4 lusin (48 buah) dengan harga Rp. 15.000 per lusin. Total biaya yang dikeluarkan untuk pembelian 4 lusin toples mika adalah sebesar Rp. 60.000 .

\section{Pemasaran Manisan Pala Ilomata}

Pemasaran adalah kegiatan penyaluran manisan pala dari produsen sampai ke konsumen. Pemasaran manisan pala Ilomata hanya memakai satu jasa lembaga pemasaran yaitu pengecer. Penyaluran manisan pala Ilomata ke pengecer dilakukan langsung oleh pemilik usaha dan anaknya. Tersedianya Sarana transportasi seperti jalan yang bagus dan alat transportasi seperti mobil yang disewa per hari sangat membantu kelancaran penyaluran manisan pala Ilomata. Manisan pala yang dihasilkan sebanyak $270 \mathrm{~kg}$, dibagi dalam 3 jenis kemasan yaitu kemasan plastik 2 ons sebanyak 500 bungkus atau $100 \mathrm{~kg}$, kemasan plastik 2,5 ons sebanyak 300 bungkus atau 75 $\mathrm{kg}$, dan kemasan toples mika 3 ons sebanyak 48 buah toples atau $14,4 \mathrm{~kg}$.

Manisan pala Ilomata disalurkan ke toko-toko di Kota Bitung seperti City Mart Bitung, City Mart Girian, MM Bitung, dan
Ruko 5. Manisan pala Ilomata juga di salurkan ke toko-toko di Kota Manado seperti Borobudur Paal 2 dan FreshMart Bahu. Pemasaran manisan pala Ilomata juga sampai ke Provinsi Gorontalo. Selain disalurkan ke beberapa toko di Kota Bitung, Manado, dan Gorontalo ada juga konsumen dari Gorontalo dan Luwuk yang singgah ke tempat produksi untuk membeli manisan pala Ilomata. Pemasaran manisan pala Ilomata di toko-toko memakai sistem laku bayar (konstinasi).

\section{Harga Jual}

Manisan pala yang dihasilkan dikemas dalam 3 ukuran kemasan dan dijual dengan harga yang berbeda sesuai ukuran kemasan. Harga manisan pala dalam setiap ukuran kemasan adalah sebagai berikut:

1. Kemasan Plastik 2 Ons

Manisan pala dalam kemasan plastik 2 ons sebanyak 500 bungkus. Harga satu bungkus Rp. 11.000, jadi total penjualan dari 500 bungkus manisan pala kemasan 2 ons adalah Rp. 5.500.000.

2. Kemasan Plastik 2,5 Ons

Manisan pala dalam kemasan plastik 2,5 ons sebanyak 300 bungkus. Harga 1 bungkus Rp. 20.000, jadi total penjualan dari 300 bungkus manisan pala kemasan 2,5 ons adalah Rp. 6.000.000.

3. Kemasan Toples Mika 3 Ons

Manisan pala dalam toples mika 3 ons sebanyak 48 buah toples. Harga 1 toples Rp. 25.000, jadi total penjualan dari 48 toples manisan pala kemasan 3 ons adalah Rp. 1.200.000.

\section{Jumlah Penjualan}

Kemasan yang digunakan untuk mengemas manisan pala Ilomata terdiri atas 500 lembar kemasan plastik 2 ons, 500 lembar 2,5 ons dan 48 buah toples mika 3 ons. Jumlah manisan pala yang disalurkan ke setiap toko di Kota Bitung, Manado, dan Gorontalo berbeda, sesuai hasil penjualan yang diperoleh dari waktu-waktu sebelumnya. Jumlah manisan pala yang didistribusikan melalui beberapa outlet adalah sebagai berikut: 
1. Manisan pala Ilomata yang disalurkan ke City Mart Bitung adalah manisan pala dalam kemasan plastik 2 ons sebanyak 100 bungkus atau $20 \mathrm{~kg}$ dan manisan pala dalam kemasan toples mika 3 ons sebanyak 24 toples atau $7,2 \mathrm{~kg}$.

2. Manisan pala yang disalurkan ke City Mart Girian adalah manisan pala dalam kemasan plastik 2 ons sebanyak 100 bungkus atau 20 $\mathrm{kg}$ dan dalam kemasan plastik 2,5 ons sebanyak 50 bungkus atau $12,5 \mathrm{~kg}$.

3. Manisan pala yang disalurkan ke MM Bitung adalah manisan pala dalam kemasan 2 ons sebanyak 100 bungkus atau $20 \mathrm{~kg}$, dalam kemasan 2,5 ons sebanyak 50 bungkus atau $12,5 \mathrm{~kg}$ dan dalam kemasan toples mika 3 ons sebanyak 24 toples atau $7,2 \mathrm{~kg}$.

4. Manisan pala yang disalurkan ke Ruko 5 adalah manisan pala dalam kemasan 2 ons sebanyak 100 bungkus atau $20 \mathrm{~kg}$ dan manisan pala dalam kemasan 2,5 ons sebanyak 50 bungkus atau $12,5 \mathrm{~kg}$.

5. Manisan pala yang disalurkan ke Borobudur Paal 2 adalah manisan pala dalam kemasan plastik 2,5 ons sebanyak 50 bungkus atau sebanyak $12,5 \mathrm{~kg}$.

6. Manisan pala yang disalurkan ke Fresh Mart Manado adalah manisan pala dalam kemasan plastik 2 ons sebanyak 100 bungkus atau 20 $\mathrm{kg}$ dan manisan pala dalam kemasan plastik 2,5 ons sebanyak 50 bungkus atau $12,5 \mathrm{~kg}$.

7. Manisan pala Ilomata yang disalurkan ke Gorontalo adalah manisan pala dalam kemasan plastik 2,5 ons sebanyak 50 bungkus atau sebanyak $12,5 \mathrm{~kg}$. Biaya yang dikeluarkan dalam kegiatan penyaluran manisan pala Ilomata berbeda-beda.

Manisan pala yang dihasilkan dalam satu kali kegiatan produksi pada bulan Mei 2016 adalah sebanyak $270 \mathrm{~kg}$. Dihitung dalam $\mathrm{kg}$, total manisan pala yang disalurkan ke tokotoko adalah sebanyak 189,4 kg. Manisan pala yang tidak disalurkan ke toko-toko adalah sebanyak 80,6 kg yang dijual langsung ke konsumen akhir (konsumen yang datang langsung ke tempat produksi membeli manisan pala Ilomata). Dihitung dalam kemasan, manisan pala yang disalurkan ke toko-toko adalah sebanyak 848 kemasan yang terbagi atas 500 bungkus manisan pala kemasan 2 ons, 300 bungkus manisan pala kemasan 2,5 ons dan 48 toples manisan pala 3 ons.

\section{Biaya Pemasaran}

Biaya pemasaranmanisan pala adalah keseluruhan biaya yang dikeluarkan untuk kegiatan pemasaran atau kegiatan penyaluran manisan pala Ilomata. Biaya-biaya tersebut terdiri atas:

1. Biaya Pengemasan dan Pengepakan

Pengemasan dan pengepakan manisan pala Ilomata dilakukan oleh 2 orang tenaga kerja borongan dan pemilik usaha. Pengemasan dan pengepakan dilakukan sebanyak 3 kali dalam satu kali produksi. Pengemasan dan pengepakkan manisan pala diberikan upah Rp. 50.000 per hari. Total biaya yang dikeluarkan untuk biaya pengemasan dan pengepakan manisan pala Ilomata pada bulan Mei adalah sebesar Rp. 200.000.

2. Biaya Pengangkutan

Kegiatan penyaluran manisan pala Ilomata dilakukan langsung oleh pemilik usaha dan anaknya. Pengangkutan kardus-kardus berisi manisan pala dilakukan oleh anak pemilik UD Ilomata.

3. Biaya Transportasi

Alat transportasi yang digunakan untuk penyaluran manisan pala Ilomata menggunakan mobil yang disewa. Penyaluran manisan pala Ilomata dilakukan sebanyak 3 kali. Biaya transportasi yang dikeluarkan untuk penyaluran manisan pala Ilomata berbeda-beda. Biaya yang dikeluarkan untuk penyaluran ke toko-toko di Kota Bitung adalah sebesar Rp. 400.000 terdiri atas biaya sewa mobil Rp. 300.000 per hari dan biaya bensin Rp. 100.000. Biaya yang dikeluarkan untuk penyaluran manisan pala Ilomata ke toko-toko di Kota Manado adalah sebesar Rp. 350.000 terdiri atas biaya sewa mobil Rp. 250.000 per hari dan biaya bensin Rp. 100.000. Biaya yang dikeluarkan untuk penyaluran manisan pala ke Gorontalo adalah sebesar Rp. 200.000. Total biaya transportasi yang dikeluarkan untuk penyaluran manisan pala Ilomata ke 
toko-toko di Kota Bitung, Manado dan Gorontalo adalah sebesar Rp. 950.000.

4. Biaya Pengiriman

Penyaluran manisan pala Ilomata diantar langsung oleh pemilik usaha sehingga tidak ada biaya pengiriman selain biaya transportasi.

\section{Lembaga Pemasaran}

Pemasaran manisan pala oleh UD Ilomata dilakukan melalui tiga saluran, saluran pemasaran melalui penjualan langsung oleh UD Ilomata, saluran pemasaran melalui beberapa outletdi Kota Bitung, dan saluran pemasaran melalui beberapa outletdi Kota Manado. Lembaga-lembaga yang terlibat dalam kegiatan pemasaran terdiri dari produsen, pengecer, dan konsumen.

\section{Produsen}

Produsen adalah perorangan atau badan usaha yang mengolah daging buah pala menjadi manisan pala, dalam hal ini UD Ilomata.

\section{Pengecer}

Pengecer adalah lembaga tata niaga yang memasarkan manisan pala Ilomata kepada konsumen, dalam hal ini, warung, toko dan supermarket yang memiliki outlet penjualan manisan pala Ilomata.

3. Konsumen

Konsumen adalah orang yang membeli manisan pala Ilomata baik secara langsung maupun secara tidak langsung melalui perantara, yaitu para pengecer.

\section{Saluran Pemasaran}

Saluran pemasaran merupakan lembagalembaga yang terlibat dalam kegiatan pemasaran manisan pala Ilomata dari produsen sampai ke konsumen. Saluran pemasaran manisan pala Ilomata adalah dari produsen ke seluruh pengencer, dari penge:ncer ke konsumen akhir

\section{Produk Sampingan}

UD Ilomata juga memproduksi beberapa produk selain manisan pala. Ada 2 produk yang diolah dari daging buah pala yaitu sirup pala dan selai. Sirup pala adalah hasil olahan dari air perasan $300 \mathrm{~kg}$ daging buah pala yang dicampur dengan bahan penolong. Dari 848 bungkus manisan pala yang disalurkan dan dijual, ada yang tidak laku (terjual). Manisan pala yang tidak terjual kemudian ditarik oleh pengusaha dan dibawa ke tempat produksi. Sisa manisan pala dicampur dengan nenas dan jadikan selai. Selain produk olahan dari daging buah pala, UD Ilomata juga memproduksi abon tuna, abon cakalang, halua kenari, dan krepek pisang.

\section{Margin Pemasaran}

Margin pemasaran adalah selisih harga yang dibayar konsumen dengan harga yang diterima produsen. Margin pemasaran adalah keseluruhan biaya yang dikeluarkan dalam proses pemasaran manisan pala Ilomata. Berdasarkan penelitian, margin pemasaran manisan pala Ilomata disetiap saluran pemasaran adalah sebagai berikut:

\section{Margin Pemasaran di Kota Bitung}

Manisan pala Ilomata disalurkan ke beberapa toko di Kota Bitung seperti City Mart Bitung, City Mart Girian, MM Bitung, dan Ruko 5.

1. Margin Pemasaran di City Mart Bitung

Manisan pala Ilomata yang dipasarkan di City Mart Bitung adalah manisan pala kemasan plastik 2 ons dan kemasan toples mika 3 ons.

Pada Tabel 3 dapat dilihat bahwa margin pemasaran manisan pala Ilomata dalam kemasan 2 ons sebesar Rp. 4.600,00 dengan share yang diterima produsen sebesar 29,48 persen. Profit margin yang diperoleh sebesar Rp. 3.764,00 dengan share sebesar 24,12 persen dari harga ditingkat konsumen. Profit margin yang diperoleh dari penjualan manisan pala kemasan 2 ons di saluran ini merupakan profit margin yang paling besar karena biaya pemasaran yang dikeluarkan kecil dan pada umumnya harga jual barang di City Mart Bitung tergolong mahal. Efisiensi pemasaran adalah sebesar 5,35 persen. 
Tabel 3. Margin Pemasaran Manisan Pala Ilomata Kemasan 2 Ons Dari Produsen Ke Pengecer City Mart Bitung Kemudian Ke Konsumen

\begin{tabular}{lccc}
\hline Unsur Biaya & $\begin{array}{c}\text { Harga } \\
(\mathrm{Rp} / \mathrm{Bks})\end{array}$ & $\begin{array}{c}\text { Biaya } \\
(\mathrm{Rp} / \mathrm{Bks})\end{array}$ & Share (\%) \\
Harga di Tingkat Produsen & $11.000,00$ & & 70,51 \\
- Manisan Pala (2 Ons) & & & \\
Biaya Pemasaran & & 167,00 & 1,07 \\
- Pengemasan, Pengepakkan $\quad$ & 669,00 & 4,05 \\
- Transportasi & 836,00 & 5,35 \\
Total Biaya & & 29,48 \\
Margin Pemasaran & $4.600,00$ & & 24,12 \\
Profit (Keuntungan) & $3.764,00$ & & \\
Harga di Tingkat Konsumen & $15.600,00$ & & \\
\hline
\end{tabular}

Pada Tabel 4 dapat dilihat bahwa margin pemasaran manisan pala Ilomata dalam kemasan 3 ons sebesar Rp. 1.500,00 dengan share yang diterima produsen sebesar 5,66 persen. Profit margin yang diperoleh sebesar Rp. 664,00 dengan share sebesar 2,50 persen. Efisiensi pemasaran adalah sebesar 3,15 persen.

2. Margin Pemasaran di City Mart Girian

3. City Mart Girian adalah manisan pala kemasan plastik 2 ons dan kemasan plastic

4. 2,5 ons.

Manisan pala Ilomata yang dipasarkan di

Pada Tabel 5 dapat dilihat bahwa margin pemasaran manisan pala Ilomata dalam kemasan 2 ons sebesar Rp. 1.500,00 dengan share yang diterima produsen sebesar 12 persen. Profit margin yang diperoleh sebesar Rp. 664,00 dengan share sebesar 5,31 persen dari harga ditingkat konsumen. Efisiensi pemasaran adalah sebesar 6,68 persen.

Pada Tabel 6 dapat diliha bahwa margin pemasaran manisan pala Ilomata dalam kemasan 2,5 ons sebesar Rp. 1.000,00 dengan share yang diterima produsen sebesar 4,76 persen. Margin pemasaran pada saluran ini merupakan margin pemasaran yang paling kecil karena selai biaya pemasaran yang dikeluarkan kecil, pada umumnya harga jual barang di City Mart Girian tergolong murah. Profit margin yang diperoleh sebesar Rp. 164,00 dengan share sebesar 0,78 persen. Efisiensi pemasaran adalah sebesar 3,98 persen.

5. Margin Pemasaran di MM Bitung

Manisan pala Ilomata yang dipasarkan MM Bitung adalah manisan pala kemasan plastik 2 ons, 2,5 ons dan kemasan toples mika 3 ons.

- Pada Tabel 7 dapat dilihat bahwa margin pemasaran manisan pala Ilomata dalam kemasan 2 ons sebesar Rp. 2.000,00 dengan share yang diterima produsen sebesar 15,38 persen. Profit margin yang diperoleh sebesar Rp. 1.164,00 dengan share sebesar 8,95 persen dari harga ditingkat konsumen. Efisiensi pemasaran adalah sebesar 6,43 persen. Pada Tabel 8 dapat dilihat bahwa margin pemasaran manisan pala Ilomata dalam kemasan 2,5 ons sebesar Rp. $2.500,00$ dengan share yang diterima produsen sebesar 11,11 persen. Profit margin yang diperoleh sebesar Rp. 1.664,00 dengan share sebesar 7,39 persen. Efisiensi pemasaran adalah sebesar 3,71 persen. 
Tabel 4. Margin Pemasaran Manisan Pala Ilomata Kemasan 3 Ons Dari Produsen Ke Pengecer City Mart Bitung Kemudian Ke Konsumen

\begin{tabular}{llll}
\hline Unsur Biaya & $\begin{array}{l}\text { Harga } \\
(\mathrm{Rp} / \mathrm{Bks})\end{array}$ & $\begin{array}{l}\text { Biaya } \\
(\mathrm{Rp} / \mathrm{Bks}\end{array}$ & $\begin{array}{l}\text { Share } \\
(\%)\end{array}$ \\
Harga di Tingkat Produsen & & \\
- Manisan Pala (3 ons) & $25.000,00$ & & \\
& & & \\
Biaya Pemasaran & & 167,00 & 0,63 \\
- Pengemasan dan Pengepakan & & 669,00 & 2,52 \\
- Transportasi & & 836,00 & 3,15 \\
- Total Biaya & & & 5,66 \\
Margin Pemasaran & $1.500,00$ & & 2,50 \\
Profit (Keuntungan) & 664,00 & & \\
Harga di Tingkat Konsumen & $26.500,00$ & \\
\hline
\end{tabular}

Tabel 5. Margin Pemasaran Manisan Pala Ilomata Kemasan 2 Ons Dari Produsen Ke Pengecer City Mart Girian Kemudian Ke Konsumen

\begin{tabular}{|c|c|c|c|}
\hline Unsur Biaya & $\begin{array}{c}\text { Harga } \\
(\mathrm{Rp} / \mathrm{Bks})\end{array}$ & $\begin{array}{c}\text { Biaya } \\
(\mathrm{Rp} / \mathrm{Bks})\end{array}$ & Share $(\%)$ \\
\hline $\begin{array}{l}\text { Harga di Tingkat Produsen } \\
-\quad \text { Manisan Pala ( } 2 \text { ons) }\end{array}$ & $11.000,00$ & & 88 \\
\hline $\begin{array}{ll}\text { Biaya Pemasaran } \\
- & \text { Pengemasan dan Pengepakan } \\
- & \text { Transportasi } \\
- & \text { Total Biaya }\end{array}$ & & $\begin{array}{l}167,00 \\
669,00 \\
836,00\end{array}$ & $\begin{array}{l}1,33 \\
5,35 \\
6,68\end{array}$ \\
\hline Margin Pemasaran & $1.500,00$ & & 12 \\
\hline Profit (Keuntungan) & 664,00 & & 5,31 \\
\hline Harga di Tingkat Konsumen & $12.500,00$ & & \\
\hline
\end{tabular}


Tabel 6. Margin Pemasaran Manisan Pala Ilomata Kemasan 2,5 Ons Dari Produsen Ke Pengecer City Mart Girian Kemudian Ke Konsumen

\begin{tabular}{|c|c|c|c|}
\hline Unsur Biaya & $\begin{array}{c}\text { Harga } \\
\text { (Rp/Bks) }\end{array}$ & $\begin{array}{c}\text { Biaya } \\
\text { (Rp/Bks) }\end{array}$ & Share $(\%)$ \\
\hline $\begin{array}{l}\text { Harga di Tingkat Produsen } \\
-\quad \text { Manisan Pala ( } 2,5 \text { ons })\end{array}$ & $20.000,00$ & & 95,23 \\
\hline $\begin{array}{ll}\text { Biaya Pemasaran } \\
- & \text { Pengemasan dan Pengepakan } \\
- & \text { Transportasi } \\
- & \text { Total Biaya }\end{array}$ & & $\begin{array}{l}167,00 \\
669,00 \\
836,00\end{array}$ & $\begin{array}{l}0,79 \\
3,18 \\
3,98\end{array}$ \\
\hline Margin Pemasaran & $1.000,00$ & & 4,76 \\
\hline Profit (Keuntungan) & 164,00 & & 0,78 \\
\hline Harga di Tingkat Konsumen & $21.000,00$ & & \\
\hline
\end{tabular}

Tabel 7. Margin Pemasaran Manisan Pala Ilomata Kemasan 2 Ons Dari Produsen Ke Pengecer MM Bitung Kemudian Ke Konsumen

\begin{tabular}{lccc}
\hline Unsur Biaya & $\begin{array}{c}\text { Harga } \\
(\mathrm{Rp} / \mathrm{Bks})\end{array}$ & $\begin{array}{c}\text { Biaya } \\
(\mathrm{Rp} / \mathrm{Bks})\end{array}$ & Share (\%) \\
$\begin{array}{l}\text { Harga di Tingkat Produsen } \\
\text { - Manisan Pala (2 ons) }\end{array}$ & $11.000,00$ & 84,61 \\
Biaya Pemasaran & & 167,00 & 1,28 \\
- Pengemasan dan Pengepakan & & 669,00 & 5,14 \\
- Transportasi $\quad$ & 836,00 & 6,43 \\
- Total Biaya & & 15,38 \\
Margin Pemasaran & $2.000,00$ & & 8,95 \\
Profit (Keuntungan) & $1.164,00$ & & \\
Harga di Tingkat Konsumen & $13.000,00$ & & \\
\hline
\end{tabular}


Tabel 8. Margin Pemasaran Manisan Pala Ilomata Kemasan 2,5 Ons Dari Produsen Ke Pengecer MM Bitung Kemudian Ke Konsumen

\begin{tabular}{lccc}
\hline Unsur Biaya & Harga & Biaya & Share \\
& $(\mathrm{Rp} / \mathrm{Bks})$ & $(\mathrm{Rp} / \mathrm{Bks})$ & $(\%)$
\end{tabular}

\section{Harga di \\ Tingkat \\ Produsen \\ - Manisan}

Biaya

Pemasaran

- Pengemasan dan Pengepakan

- Transportasi

- Total Biaya

\begin{tabular}{lcc}
$\begin{array}{l}\text { Margin } \\
\text { Pemasaran }\end{array}$ & $2.500,00$ & 11,11 \\
$\begin{array}{l}\text { Profit } \\
\text { (Keuntungan) }\end{array}$ & $1.664,00$ & 7,39 \\
$\begin{array}{l}\text { Harga di } \\
\text { Tingkat } \\
\text { Konsumen }\end{array}$ & $22.500,00$ & \\
\hline
\end{tabular}

Pada Tabel 9 dapat dilihat bahwa margin pemasaran manisan pala Ilomata dalam kemasan 3 ons sebesar Rp. 1.500,00 dengan share yang diterima produsen sebesar 5,66 persen. Profit margin yang diperoleh sebesar Rp. 664,00 dengan share sebesar 2,50 persen. Efisiensi pemasaran adalah sebesar 3,15 persen.

Tabel 9. Margin Pemasaran Manisan Pala Ilomata Kemasan 3 Ons Dari Produsen Ke Pengecer MM Bitung Kemudian Ke Konsumen

\begin{tabular}{lccc}
\hline Unsur Biaya & $\begin{array}{c}\text { Harga } \\
(\mathrm{Rp} / \mathrm{Bks})\end{array}$ & $\begin{array}{c}\text { Biaya } \\
(\mathrm{Rp} / \mathrm{Bks})\end{array}$ & $\begin{array}{c}\text { Share } \\
(\%)\end{array}$ \\
Harga di Tingkat & & & \\
\hline
\end{tabular}

\begin{tabular}{lccc}
\hline $\begin{array}{l}\text { Produsen } \\
-\quad \text { Manisan Pala }\end{array}$ & $25.000,00$ & & 94,33 \\
$\begin{array}{l}\text { (3 ons) } \\
\text { Biaya Pemasaran }\end{array}$ & & & \\
$-\quad \begin{array}{l}\text { Pengemasan } \\
\text { dan }\end{array}$ & & 167,00 & 0,63 \\
$\quad \quad \begin{array}{l}\text { Pengepakan } \\
\text { Transportasi }\end{array}$ & & 869,00 & 2,52 \\
$-\quad$ Total Biaya & & & \\
$\begin{array}{l}\text { Margin } \\
\text { Pemasaran } \\
\text { Profit } \\
\text { (Keuntungan) }\end{array}$ & $1.500,00$ & & 5,66 \\
$\begin{array}{l}\text { Harga di Tingkat } \\
\text { Konsumen }\end{array}$ & $26.500,00$ & & \\
\hline
\end{tabular}

6. Margin Pemasaran di Ruko 5 Manisan pala Ilomata yang dipasarkan Ruko 5 adalah manisan pala kemasan plastik 2 ons, 2,5 ons.

Tabel 10. Margin Pemasaran Manisan Pala Ilomata Kemasan 2 Ons Dari Produsen Ke Pengecer Ruko 5 Kemudian Ke Konsumen

\begin{tabular}{cccc}
\hline Unsur Biaya & Harga & Biaya & Shar \\
& $(\mathrm{Rp} / \mathrm{Bks})$ & $(\mathrm{Rp} / \mathrm{Bks}$ & $\mathrm{e}(\%)$
\end{tabular}

Harga di

Tingkat

Produsen

$$
11.000,0
$$

91,6

- Manisan

0

6

Biaya

Pemasaran

167,00

- Pengemasan

669,00

5,57

dan

836,00

6,96

Transpakan

Transportas i

- Total Biaya

Margin

Pemasaran

$1.000,00$

Profit

(Keuntungan) $\quad 164,00$

Harga di

Tingkat

Konsumen 
Tabel 11. Margin Pemasaran Manisan Pala Ilomata Kemasan 2,5 Ons Dari Produsen Ke Pengecer Ruko 5 Kemudian Ke Konsumen

\begin{tabular}{cccc}
\hline Unsur Biaya & Harga & Biaya & Shar \\
& $(\mathrm{Rp} / \mathrm{Bks})$ & $(\mathrm{Rp} / \mathrm{Bks}$ & $\mathrm{e}$ \\
& & ) & $(\%)$
\end{tabular}

Harga di

Tingkat

Produsen

$20.000,0$

93,0

- Manisan

0

2

Pala $(2,5$

ons)

Biaya

Pemasaran

- Pengemasa

n dan

Pengepaka

n

- Transporta

si

- Total Biaya

Margin

Pemasaran $\quad 1.500,00$

$167,00 \quad 0,77$

$669,00 \quad 3,11$

$836,00 \quad 3,98$

Profit

(Keuntungan) $\quad 664,00$

Harga di

Tingkat

$21.500,0$

Konsumen

0

Pada Tabel 11 dapat dilihat bahwa margin pemasaran manisan pala Ilomata dalam kemasan 2,5 ons sebesar Rp. 1.500,00 dengan share yang diterima produsen sebesar 6,97 persen. Profit margin yang diperoleh sebesar Rp. 664,00 dengan share sebesar 3,16 persen. Efisiensi pemasaran adalah sebesar 3,98 persen.

\section{Margin Pemasaran di Kota Manado}

Manisan pala Ilomata juga disalurkan ke beberapa toko di Kota Manado seperti Borobudur Paal 2 dan Fresh Mart Bahu.

1. Margin Pemasaran di Borobudur Paal 2

Manisan pala Ilomata yang dipasarkan di Borobudur Paal 2 adalah manisan pala kemasan plastik 2,5 ons.
Tabel 12. Margin Pemasaran Manisan Pala Ilomata Kemasan 2,5 Ons Dari Produsen

Ke Pengecer Borobudur Paal 2 Kemudian Ke Konsumen

\begin{tabular}{cccc}
\hline Unsur Biaya & Harga & Biaya & Shar \\
& $(\mathrm{Rp} / \mathrm{Bks})$ & $(\mathrm{Rp} / \mathrm{Bks}$ & $\mathrm{e}$ \\
& & ) & $(\%)$
\end{tabular}

Harga di

Tingkat

$20.000,0$

Produsen

0

86,9

- Manisan

5

Pala $(2,5$

ons)

Biaya

Pemasaran

- Pengemasa 200,00 0,86

n dan

Pengepaka

n

- Transporta

si

$1.750,0$

$0 \quad 7,60$

$1.950,0$

0

8,47

- Total Biaya

Margin

Pemasaran

$3.000,00$

4

Profit

$\begin{array}{lll}\text { (Keuntungan) } \quad 1.050,00 & 4,56\end{array}$

Harga di

$23.000,0$

Tingkat

0

Konsumen

Pada Tabel 12 dapat dilihat bahwa margin pemasaran manisan pala Ilomata dalam kemasan 2,5 ons sebesar Rp. 3.000,00 dengan share yang diterima produsen sebesar 13,04 persen. Profit margin yang diperoleh sebesar Rp. 1.050,00 dengan share sebesar 4,56 persen dari harga ditingkat konsumen. Efisiensi pemasaran adalah sebesar 8,47 persen.

2. Margin Pemasaran di Fresh Mart Bahu

Manisan pala Ilomata yang dipasarkan di Fresh Mart Bahu adalah manisan pala kemasan plastik 2 ons dan kemasan plastik 2,5 ons. 
Tabel 13. Margin Pemasaran Manisan

Pala Ilomata Kemasan 2 Ons Dari

Produsen Ke Pengecer Fresh Mart Bahu Kemudian Ke Konsumen

\begin{tabular}{cccc}
\hline Unsur Biaya & Harga & Biaya & Shar \\
& $(\mathrm{Rp} / \mathrm{Bks})$ & $(\mathrm{Rp} / \mathrm{Bks}$ & $\mathrm{e}$ \\
& & ) & $(\%)$
\end{tabular}

Harga di

Tingkat

Produsen

$11.000,0$

- Manisan

0

Pala 2 ons

Biaya

Pemasaran

- Pengemasa

n dan

Pengepaka

n

- Transporta

si

- Total Biaya

$1.950,0$

0

\begin{tabular}{llc}
$\begin{array}{l}\text { Margin } \\
\text { Pemasaran }\end{array}$ & $2.000,00$ & 15,3 \\
Profit & & 8,38 \\
(Keuntungan) & 50,00 & \\
$\begin{array}{l}\text { Harga di } \\
\text { Tingkat }\end{array}$ & $13.000,0$ & \\
Konsumen & 0 & \\
\hline
\end{tabular}

Pada Tabel 13 dapat dilihat bahwa margin pemasaran manisan pala Ilomata dalam kemasan 2 ons sebesar Rp. 2.000,00 dengan share yang diterima produsen sebesar 15,38 persen. Profit margin yang diperoleh sebesar Rp. 50,00 dengan share sebesar 0,38 persen dari harga ditingkat konsumen. Profit margin yang diperoleh dari penjualan manisan pala kemasan 2 ons di saluran ini merupakan profit margin yang paling kecil karena biaya pemasaran yang dikeluarkan kecil karena biaya pemasaran yang dikeluarkan besar dengan margin pemasaran yang diterima kecil. Efisiensi pemasaran adalah sebesar 15 persen.
Tabel 14. Margin Pemasaran Manisan Pala Ilomata Kemasan 2,5 Ons Dari Produsen

Ke Pengecer Fresh Mart Bahu Kemudian Ke Konsumen

\begin{tabular}{cccc}
\hline Unsur Biaya & Harga & Biaya & Shar \\
& $(\mathrm{Rp} / \mathrm{Bks})$ & $(\mathrm{Rp} / \mathrm{Bks}$ & $\mathrm{e}$ \\
& & ) & $(\%)$
\end{tabular}

Harga di

Tingkat

Produsen

$$
20.000,0
$$

88,8

- Manisan

$$
0
$$

8

Pala $(2,5$

ons)

Biaya

Pemasaran

- Pengemasa 200,00 0,88

$$
\text { n dan }
$$

Pengepaka

n

- Transporta

0

si

- Total Biaya

$1.950,0$

0

Margin

Pemasaran

$2.500,00$

1

Profit

(Keuntungan) $\quad 550,00 \quad 2,44$

\section{Harga di}

Tingkat $\quad 22.500,0$

Konsumen

0

Pada Tabel 14 dapat dilihat bahwa margin pemasaran manisan pala Ilomata dalam kemasan 2,5 ons sebesar Rp. 2.500,00 dengan share yang diterima produsen sebesar 11,11 persen. Profit margin yang diperoleh sebesar Rp. 550,00 dengan share sebesar 2,44 persen. Efisiensi pemasaran adalah sebesar 8,66 persen.

\section{Margin Pemasaran di Gorontalo}

Manisan pala Ilomata di salurkan ke satu toko milik kerabat UD Ilomata di Gorontalo. 
Tabel 15. Margin Pemasaran Manisan Pala Ilomata Kemasan 2,5 Ons Dari Produsen Ke Pengecer Fresh Mart Bahu Kemudian Ke Konsumen

\begin{tabular}{lccc}
\hline Unsur Biaya & $\begin{array}{c}\text { Harga } \\
(\mathrm{Rp} / \mathrm{Bks})\end{array}$ & $\begin{array}{c}\text { Biaya } \\
(\mathrm{Rp} / \mathrm{Bks})\end{array}$ & $\begin{array}{c}\text { Share } \\
(\%)\end{array}$ \\
$\begin{array}{l}\text { Harga di Tingkat } \\
\text { Produsen }\end{array}$ & & \\
$-\quad \begin{array}{l}\text { Manisan Pala } \\
\quad 2,5 \text { ons) }\end{array}$ & $20.000,00$ & & \\
$\begin{array}{l}\text { Biaya Pemasaran } \\
\text { - Transportasi }\end{array}$ & & & \\
- Total Biaya & & $4.000,00$ & 16 \\
$\quad$ & $4.000,00$ & 16 \\
$\begin{array}{l}\text { Margin } \\
\text { Pemasaran } \\
\text { Profit } \\
\text { (Keuntungan) }\end{array}$ & $1.000,00$ & & \\
Harga di Tingkat & & & \\
Konsumen & $25.000,00$ & & \\
\hline
\end{tabular}

Pada Tabel 15 dapat dilihat bahwa margin pemasaran manisan pala Ilomata dalam kemasan 2,5 ons sebesar Rp. 5.000,00 dengan share yang diterima produsen sebesar 20 persen. Margin pemasaran pada saluran ini merupakan margin pemasaran yang paling besar. Margin pemasaran pada saluran ini merupakan margin pemasaran yang paling besar. Hal ini disebabkan oleh jauhnya jarak antara produsen dengan pengecer sehingga harga jual manisan pala Ilomata menjadi mahal. Selain harga yang mahal, hal tersebut dikarenakan oleh kurangnya kepercayaan dari pemilik usaha untuk menyalurkan manisan pala dalam jumlah yang banyak. Profit margin yang diperoleh sebesar Rp. 1.000,00 dengan share sebesar 4 persen. Efisiensi pemasaran adalah sebesar 16 persen.

\section{Break Event Point (BEP)}

Break Event Point (BEP) adalah suatu keadaan dimana laba (keuntungan) sama dengan nol atau titik pulang pokok.

a. Break Event Point (BEP) Manisan Pala Dalam Kemasan Plastik 2 ons (200 gram)

Total manisan pala kemasan 2 ons (200 gram) yang disalurkan ke toko-toko sebanyak 500 bungkus dengan harga Rp. 11.000 per bungkus. Total penerimaan dari penjualan 500 bungkus manisan pala dalam kemasan 2 ons (200 gram) adalah sebesar Rp. 5.500.000.

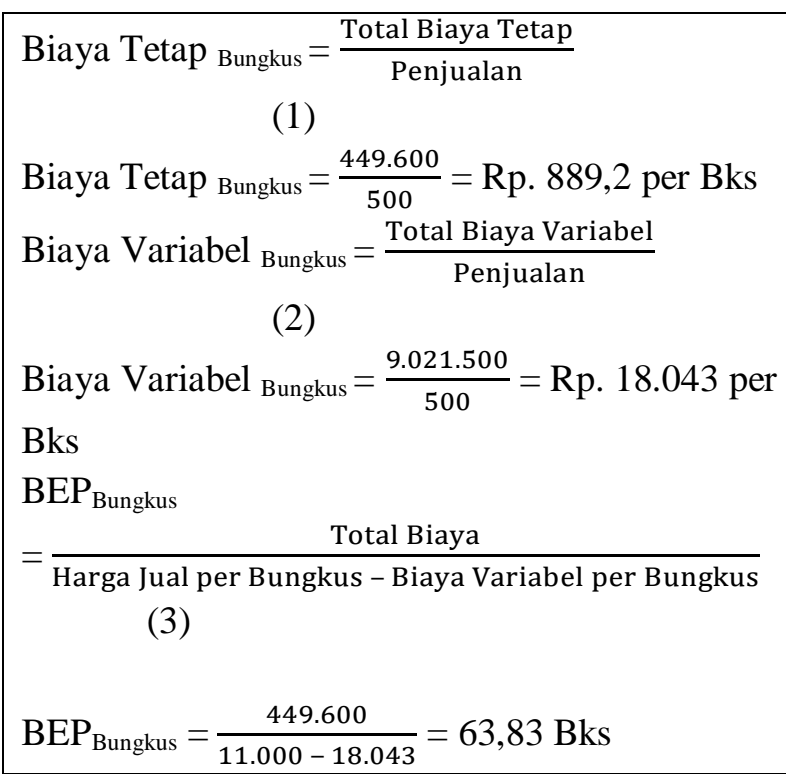

Jadi, UD Ilomata harus menjual manisan pala dalam kemasan 2 ons sebanyak 63,83 bungkus agar terjadi BEP atau perusahaan harus mendapat omset sebesar Rp. 702.130 yang diperoleh dari hasil BEP per bungkus dikali harga jual manisan pala kemasan 2 ons (200 gam).

b. Break Event Point (BEP) Manisan Pala Dalam Kemasan Plastik 2,5 Ons (250 gram)

Total manisan pala kemasan 2,5 ons (250 gram) yang disalurkan ke toko-toko sebanyak 500 bungkus dengan harga Rp. 20.000 per bungkus. Total penerimaan dari penjualan 500 bungkus manisan pala dalam kemasan 2,5 ons (250 gram) adalah sebesar Rp. 10.000.000.

Biaya Tetap Bungkus $=\frac{\text { Total Biaya Tetap }}{\text { Penjualan }}$

(4)

Biaya Tetap Bungkus $=\frac{449.600}{500}=$ Rp. 889,2 per Bks Biaya Variabel $_{\text {Bungkus }}=\frac{\text { Total Biaya Variabel }}{\text { Penjualan }}$

(5)

Biaya Variabel $_{\text {Bungkus }}=\frac{9.021 .500}{500}=$ Rp. 18.043 per Bks

$\mathrm{BEP}_{\text {Bungkus }}$

$=\frac{\text { Harga Jual per Bungkus - Biaya Variabel per Bungkus }}{\text { Hotal }}$ (6)

$\mathrm{BEP}_{\text {Bungkus }}=\frac{449.600}{20.000-18.043}=229,73 \mathrm{Bks}$ 
Jadi, UD Ilomata harus menjual manisan pala dalam kemasan 2,5 ons $(250$ gram) sebanyak 229,73 bungkus agar terjadi BEP atau perusahaan harus mendapat omset sebesar Rp. 4.394.600 yang diperoleh dari hasil BEP per bungkus dikali harga jual manisan pala kemasan 2,5 ons (250 gram).

c. Break Event Point (BEP) Manisan Pala Dalam Kemasan Toples Mika 3 Ons (300 gram)

Total manisan pala kemasan 3 ons (300 gram) yang tdisalurkan sebanyak 48 toples dengan harga Rp. 25.000 per toples. Total penerimaan dari penjualan 48 toples manisan pala dalam kemasan 3 ons (300 gram) adalah sebesar Rp. 1.200.000.

\begin{tabular}{|c|}
\hline $\begin{array}{c}\text { Biaya Tetap Toples }=\frac{\text { Total Biaya Tetap }}{\text { Penjualan }} \\
\text { (7) }\end{array}$ \\
\hline $\begin{array}{l}\text { Biaya Tetap Toples }=\frac{449.600}{48}=\text { Rp. } 9.366 \text { per } \\
\text { Toples }\end{array}$ \\
\hline $\begin{array}{c}\text { Biaya Variabel } \\
\text { Toples } \\
(8)\end{array}$ \\
\hline $\begin{array}{l}\text { Biaya Variabel }{ }_{\text {Toples }}=\frac{9.021 .500}{48}=\text { Rp. } 187.947 \\
\text { per Toples } \\
\text { BEP }_{\text {Toples }}\end{array}$ \\
\hline $\begin{array}{l}= \\
\text { Harga Jual per toples - Biaya Variabel per Toples } \\
\text { (9) }\end{array}$ \\
\hline $\mathrm{BEP}_{\text {Toples }}=\frac{449.600}{25.000-187.947}=2,75$ Toples \\
\hline
\end{tabular}

Jadi, UD Ilomata harus menjual manisan pala dalam kemasan 3 ons sebanyak 2,75 toples agar terjadi BEP atau perusahaan harus mendapat omset sebesar Rp. 67.750 yang diperoleh dari hasil BEP per bungkus dikali harga jual manisan pala kemasan 3 ons (300 gram).

\section{KESIMPULAN DAN SARAN Kesimpulan}

Berdasarkan hasil penelitian, proses pembuatan manisan pala adalah Pengupasan buah pala, pembentukkan variasi bentuk manisan, Pencucian daging buah pala dari getah, Pemipihan atau pengepressan daging buah pala untuk memisahkan daging dari air, dan Peredaman II dengan gula pasir dan garam. Manisan pala yang dihasilkan, dikemas dalam tiga jenis kemasan yaitu kemasan plastik ukuran 2 ons, kemasan plastik ukuran 2,5 ons, dan toples mika ukuran 3 ons. Manisan pala Ilomata disalurkan ke beberapa toko di Kota Bitung, Manado, dan Gorontalo memakai sistem laku bayar (konstinasi). Jumlah manisan pala yang disalurkan ke setiap toko berbeda yaitu: CityMart Bitung sebanyak 100 bungkus kemasan 2 ons dan 24 toples kemasan 3 ons, CityMart Girian sebanyak 100 bungkus kemasan 2 ons dan 50 bungkus kemasan 2,5 ons, MM Bitung sebanyak 100 bungkus kemasan 2 ons, 50 bungkus kemasan 2,5 ons dan 24 toples kemasan 3 ons, Ruko 5 sebanyak 100 bungkus kemasan 2 ons dan 50 bungkus kemasan 2,5 ons, Borobudur sebanyak 50 bungkus kemasan 2,5 ons, Fresh MartBahu Manado sebanyak 100 bungkus kemasan 2 ons dan 50 bungkus kemasan 2,5 ons, Gorontalo sebanyak 50 bungkus kemasan 2,5 ons. Selain disalurkan ke beberapa toko, ada juga konsumen dari Gorontalo dan Luwuk yang singgah ke tempat produksi (UD Ilomata) untuk membeli manisan pala. Biaya pemasaran yang paling kecil adalah biaya pemasaran yang dikeluarkan pada saluran di Kota Bitung yaitu sebesar Rp. 836,00/ bungkus. Margin pemasaran yang paling besar yaitu sebesar Rp. 5.000 per bungkus pada penjualan manisan pala Ilomata dalam kemasan 2,5 ons berada di saluran pemasaran di Gorontalo. Profit margin paling besar yaitu sebesar Rp. 3.764 per bungkus pada penjualan manisan pala Ilomata dalam kemasan 2 ons berada di saluran pemasaran di CityMart Bitung. Semua saluran pemasaran manisan pala Ilomata dapat dikatakan efisien karena total biaya yang dikeluarkan kecil dilihat dari perputaran waktu lama laku produk. Usaha manisan pala dari UD Ilomata bisa bertahan dan eksis sampai sekarang berkat adanya ketekunan, rasa ingin tahu serta jiwa wirausaha dari pemilik yaitu Ibu Renny Umar.

\section{Saran}

Bagi pengusaha untuk menjaga kualitas produk manisan pala agar tetap diminati konsumen, perlu adanya inovasi produk seperti memproduksi manisan pala kering dan 
penyaluran manisan pala ke Gorontalo diperbanyak melihat banyaknya peminat walaupun harga manisan pala Ilomata terbilang mahal. Bagi peneliti selanjutnya agar lebih teliti dalam pengumpulan data.

\section{DAFTAR PUSTAKA}

Abdullah dan Tatri, 2012. Manajemen Pemasaran. PT Raja Grafindo Persada. Jakarta.

Adisaputro, G., 2014. Manajemen Pemasaran (Analisis Untuk Perencanaan Strategi Pemasaran). Unit Penerbit Sekolah Tinggi Ilmu Manajemen YKPN. Yogyakarta.

Adiwilaga, 1996. Ilmu Usaha Tani. Penerbit Alumni Bandung. Bandung

Anindita, R., 2004. Pemasaran Hasil Pertanian. Papirus. Surabaya.

Astanu, D. A., R.H. Ismuno \& N. Rosanti. 2013. Analisis Kelayakan Finansial Budidaya Intensif Tanaman Pala di Kecamatan Gisting Kabupaten Tanggamus. Vol. 1. No. 3 Hal 218 dan 224. Lampung: Fakultas Pertanian. Jurusan Agribisnis. Universitas Lampung. https://scholar.google.co.id/scholar?hl=id\& q+Astanu\%2C+Ismuno\%2C+Rosanti+2013 + Aalisis+Kelayakan+Finansial+Budidaya + Intensif+Tanaman+Pala+di+Kecamatan+Gi sting+Tanggamus\&btnG $=$. Diakses $20 \mathrm{Juni}$ 2016.

Assauri, S., 2014. Manajemen Pemasaran (Dasar, Konsep, dan Strategi). PT RajaGrafindo Persada. Jakarta.

Gagola, L., 2003. Pemasaran Panili di Kecamatan Lirung Kabupaten Talaud. Manado: Fakultas Pertanian. Universitas sam Ratulangi.

Halim, A. dan S. Bambang. 2005. Akuntansi Manajemen. Edisi Pertama. BPFE. Yogyakarta.

Hanafie, R., 2010. Pengantar Ekonomi Pertanian. Penerbit Andi. Yogyakarta.

Handayani, S. Mulya \& I. Nurlaila. 2011. Analisis Pemasaran Susu Segar di Desa Kayumas Kecamatan Jatinom Kabupaten Klaten. Vol. 9 . No. 1. Hal 42. Surakarta: Jurusan Agribisnis. Fakultas Pertanian. Universitas Sebelas Maret Surakarta. https://scholar.google.co.id/scholar?hl=id\&
q=Hndayani+dan+Nurlaila $+2011+$ Analisis +Pemasaran+Susu+Segar+di+Desa+Kayum as+Kecamatan+Jatinom+Kabupaten+Klate n\&btnG=. Diakses 20 Juni 2016)

Hansen dan Mowen., 2001. Manajemen Biaya. Edisi Bahasan Indonesia Buku Dua Edisi Pertama. Salemba Empat. Jakarta.

Ibrahim, Y., 2009. Studi Kelayakan Bisnis. PT Rineka Cipta. Jakarta.

Imam, H., 2003. Pemasaran Beras di Kecamatan Lolayan (Studi Kasus Desa Tungoi I dan Tonaya Selatan). Manado: Fakultas Pertanian. Universitas Sam Ratulangi.

Jumiati, E., D.H. Darwanto. S. Hartono \& Masyhuri. 2013. Analisis Pemasaran dan Margin Pemasaran Kelapa Dalam di Daerah Perbatasan Kalimantan Timur. Yogyakarta: Vol. 12. No. 1. Hal 4. Agribisnis Fakultas Pertanian Universitas Borneo dan Fakultas Ekonomi Pertanian Universitas Gajah Mada. https://scholar.google.co.id/scholar?hl=id\& $\mathrm{q}=$ jumiati\%2C+Darwanto $\% 2 \mathrm{C}+\mathrm{Hartono}+\mathrm{d}$ an+Masyhuri+2013+Analisis+Pemasaran+ dan+Margin+Pemasaran+Kelapa+Dalam + d i+Daerah+Perbatasan+Kalimantan+Timur

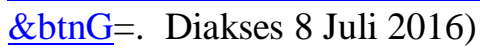

Kotler dan Keller, 2004. Manajemen Pemasaran. PT Prenhallindo. Jakarta.

Mamarimbing, M., 2004. Pemasaran Buncis (Phaeseolus Vulgaris L) di Desa Wailan Kecamatan Tomohon Utara Kota Tomohon. Manado: Jurusan Sosial Ekonomi Fakultas Pertanian. Universitas Sam Ratulangi.

Mandak, S., 2000. Pemasaran Pala di Puau Siau. Manado: Jurusan Sosial Ekonomi. Fakultas Pertanian. Universitas Sam Ratulangi.

Moehar, D., 2002. Pengantar Ekonomi Pertanian. PT Bumi Aksara. Jakarta.

Mulyadi, 2005. Akuntansi Biaya. Edisi ke Enam. STIE YKPN. Yogyakarta.

Pasaribu, A., 2012. Perencanaan dan Evaluasi Proyek Agribisnis. Penerbit Andi. Yogyakarta.

Simamora, H., 2002. Akuntansi Manajemen. Salemba Empat. Jakarta.

Simatupang, P., 2004. Prospek Usaha dan Pemasaran Beberapa Komoditas Pertanian. Pusat Penelitian dan Pengembangan Sosial Ekonomi Pertanian. Bogor.

Soeharno, TS., 2007. Teori Mikro Ekonomi. Penerbit ANDI. Yogyakarta. 
Soekartawi, 2002. Prinsip Dasar Manajemen Hasil-Hasil Pertanian (Teori dan Aplikasinya). PT RajaGrafindo Persada. Jakarta.

2002. Analisis Usahatani. Universitas Jakarta. Jakarta.

Soetanto, 2001. Manisan Buah-Buahan. Kanisius (Anggota IKAPI). Yogyakarta.

Sudiyono, A., 2002. Pemasaran Pertanian. Universitas Muhammadiyah. Malang.

Suluh, V., 2015. Nilai Ekonomi Tanaman Pala di Desa Kauditan Kecamatan Kauditan Kabupaten Minahasa Utara. Manado: Jurusan Sosial Ekonomi. Fakultas Pertanian. Universitas Sam Ratulangi.

Supit, M., 2015. Evaluasi Kelayakan Usaha Pengolahan Daging Buah Pala di Desa Karegesan Kecamatan Kauditan Kabupaten Minahasa Utara. Manado: Jurusan Sosial Ekonomi. Fakultas Pertanian Universitas Sam Ratulangi.
Suwardi, P., 2012. Analisis Keuntungan dan Nilai Tambah Agriindustri Manisan Pala UD Putri di Kota Bitung. Manado: Jurusan Sosial Ekonomi. Fakultas Pertanian. Universitas Sam Ratulangi.

Tampi, L., 2002. Analisis Efisiensi Pemasaran Kubis Bunga Kecamatan Tomohon. Manado: Fakultas Pertanian. Universitas Sam Ratulangi.

Widiastuti, N. dan M. Harisudin. 2013. Saluran dan Margin Pemasaran Jagung di Kabupaten Grobogan. Vol. 9. No. 2. Hal. 235. Dinas Pertanian Tanaman Pangan dan Hortikultura Kabupaten Grobogan dan Staf Pengajar Program Studi Agribisnis Fakultas Pertanian Universitas Sebelas Maret.

https://scholar.google.co.id/scholar?hl=id\& $\mathrm{q}=$ Widiastuti+dan+Harisudin $+2013+$ Salura $\mathrm{n}+$ dan+Margin+Pemasaran+Jagung+di+Ka bupaten+Grobogan\&btnG=. Diakses 12 April 2016) 